\title{
KINEMATICS OF MASS PHENOMENA ON THE EXAMPLE OF AN ACTIVE LANDSLIDE MONITORED USING GPS AND GBINSAR TECHNOLOGY
}

\author{
Anna Szafarczyk ${ }^{1}$ \\ ${ }^{1}$ AGH University of Science and Technology
}

The process of landslides is often carried out over long periods of time and is conditioned by the action of three groups of factors: an accidental, cyclical and main factor. The separation of the long-term tendency (isolation of the main factor) requires elimination of the seasonal (cyclic) and accidental factor. The article presents the results of geodesic surveys of a selected landslide, which was activated by opencast mining. Geodetic measurements were carried out with a ground based radar interferometer in GBInSAR technology and a GPS receiver in RTN technology. For the obtained data, a method was presented that allows to isolate a cyclic factor in a 24-hour period. The elimination of the cyclical factor allowed to distinguish the long-term tendency and determine the nature of the trend.

Key words: Open cast mine, Landslide, Displacement monitoring, Geodetic measurements, Technology, Kinematics

\section{INTRODUCTION}

The landslide process is a natural process occurring in nature, leading to peneplain, i.e. levelling the Earth surface and balancing the ground masses. This process takes time, in favourable geological conditions, and its dynamics is connected with the amount of the water inflowing as a result of the occurring precipitation and possible meltdown.

Landslides can occur naturally, because of unfavourable stability conditions on the slope, but they can also be activated by external natural factors (earthquakes, tsunami) or by human activities (cutting the slope).

In the open-cast mines areas, landslides are formed as a result of the carried out mining activities. The permanent escarpment formation in the open excavation disturbs the initial state of balance. Loss of slope stability, leads to mass movements, and earth masses move towards the bottom of the open pit, where the machines are located, and people work. This is a serious hazard to the safety of machines and the health and life of staff.

\section{LANDSLIDES CLASSIFICATION}

Due to the complexity of the landslide phenomenon, many classifications of landslides were made, applying different criteria of division. Among the best known classifications, Varnes' division [1] and Cruden- Varnes' division [2] should be mentioned, where the main criteria of division are: type of movement (falls, topples, slides, spreads, flows) and the type of transported material (rock, debris, earth).

Classification by Savarensky [3] is based on the features of the land sliding process mechanism, represented by the position of the displacement of the surface in relation to the structure of the rocks the landslide slope consists of. All landslides are divided into three classes: asequent, consequent and insequent. Pavlov's classification [4] covers all landslides which are divided into two classes on the basis of shear force direction in relation to landslide slope: delapsive landslides and detrusive landslides. Sharpe [5] introduced a three-dimensional classification system recognizing the type of movement, material and movement velocity. He also coined (presumably) the important terms of the debris flow (channelled), debris avalanche (open-slope), and earth flow.

\section{LANDSLIDES ISSUES IN POLAND}

Landslide areas are of a limited use for investment purposes, including residential, industrial or service development [6]. For this reason they should be recognized, recorded and monitored in order to ensure security, which is implemented by various technologies such as unmanned aerial vehicles [7], geophysical methods [8], Lidar [9] or InSAR [10]. The first registration of natural landslides, carried out in Poland in the late 1960s, showed the existence of more than 3,000 landslides on the Carpathian slopes, the number of which increased to 20,000 as further exploratory work was carried out. Currently, it is estimated that there are around 50,000 landslides in Poland [11].

Landslide movements hazard in mining areas in Poland are equally serious and dangerous. Exploitation in an open-pit mine, conducted without constant monitoring of slope deformation processes, could pose a hazard to the life of the crew, and the mining plant expose to financial losses related to the destruction of equipment and suspension of production [12]. An example of this is the large landslides in the opencast brown coal mine "Bełchatów", which expose the mine to various types of hazards and losses of the deposit reaching tens of millions of zlotys. 
It is therefore necessary to constantly monitor the deformation of slopes and slopes of the mine in areas selected on the basis of geological structure in order to warn against catastrophic deformations (landslides). This allows you to withdraw mining machines and crew from hazardous areas on time.

\section{CHARACTERISTICS OF THE LANDSLIDE PROCES AND ITS MEASUREMENTS}

Landslide is a continual process, depending on external factors, which was illustrated in the form of diagram by Karl Terzaghi, in 1950, indicating changes in the state of balance and the landslide activity in time [13]. Landslides can be repeated, even many times (e.g., every spring) or occur incidentally. The time of lasting of every phase varies and depends on the character and intensity of the operating factors.

Wysokiński [14] formed the criterion of the assessment of the dynamics of slopes, defining allowed values of horizontal dislocations the occurrence of which still does not activate landslide. These values result from observation and experience. The criteria of assessing the dynamics, depending on the objective of the research and class of the object are different. For example, it can be stated that for the typical constructions, the value of the dangerous difference in horizontal dislocations on the length of the object (on average about 30 metres), ranges from 1 to 3 $\mathrm{cm}$, while for scarps in an open cast mine the acceptable value can even reach 1 metre.

Based on the results of the landslide observations made by the team of geologists and geo-technicians on one of the Polish open-cast mines [15], the relationships between the occurring values and phases of the landslide movement was illustrated in a scheme (Fig. 1).

In the studies on the surface mass movements kinematics an important role was played by the surveying measurements made in series, with various techniques [16].
In the case of applying classical technologies, permanently stabilized geodetic points (node marks), the situation of which is expressed in coordinates $\mathrm{X}, \mathrm{Y}, \mathrm{H}$ in the obligatory coordinates system is marked in time intervals, depending on the process speed [17]. Modern deformation measurements are based on the use of remote techniques, such as scanning or ground based radar interferometry [18], [19], which are successfully applied worldwide, and the description of experience connected with its applications is available in many publications [20], [21], [22]. In the landslide monitoring and the analysis of the surveying measurements results, also other methods are applied, such as kriging [23], marking the surface tensor of strains with surveying methods [24] and others.

\section{RESEARCH AREA AND MEASUREMENT TECHNOLOGY}

The studied object was one of the landslides located in the selected open cast pit area in Poland. The geological profile of the landslide was presented in Fig. 2.

As part of the conducted research, the measurements results carried out in the ground radar interferometry technology (IBIS L radar) were used.

They were confronted with the results of classical measurements of geodetic points grid. The studies included the use of points $\mathrm{X}, \mathrm{Y}, \mathrm{H}$ coordinates distributed in the landslide area, as shown in Fig. 3.

This grid is surveyed by the mine staff, usually in oneweek series, applying technologies of GPS RTK, and total stations. The obtained points coordinates values are applied in the determination of the values of horizontal dislocations, vertical dislocations and their speed.

The basic measurement method, tested in the existing conditions was ground based radar interferometry (GBInSAR) Fig. 4.

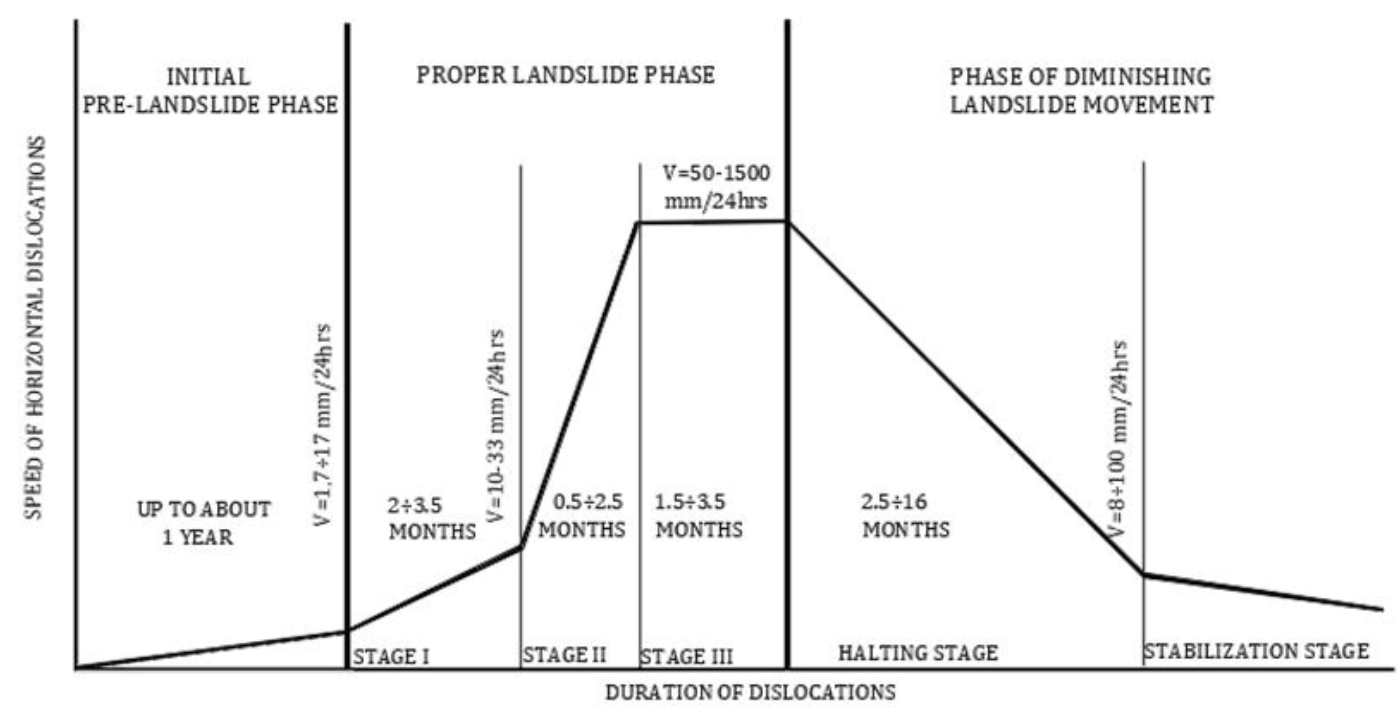

Figure 1: The speed of horizontal dislocations - results of the landslide observations of an exemplary open cast pit 


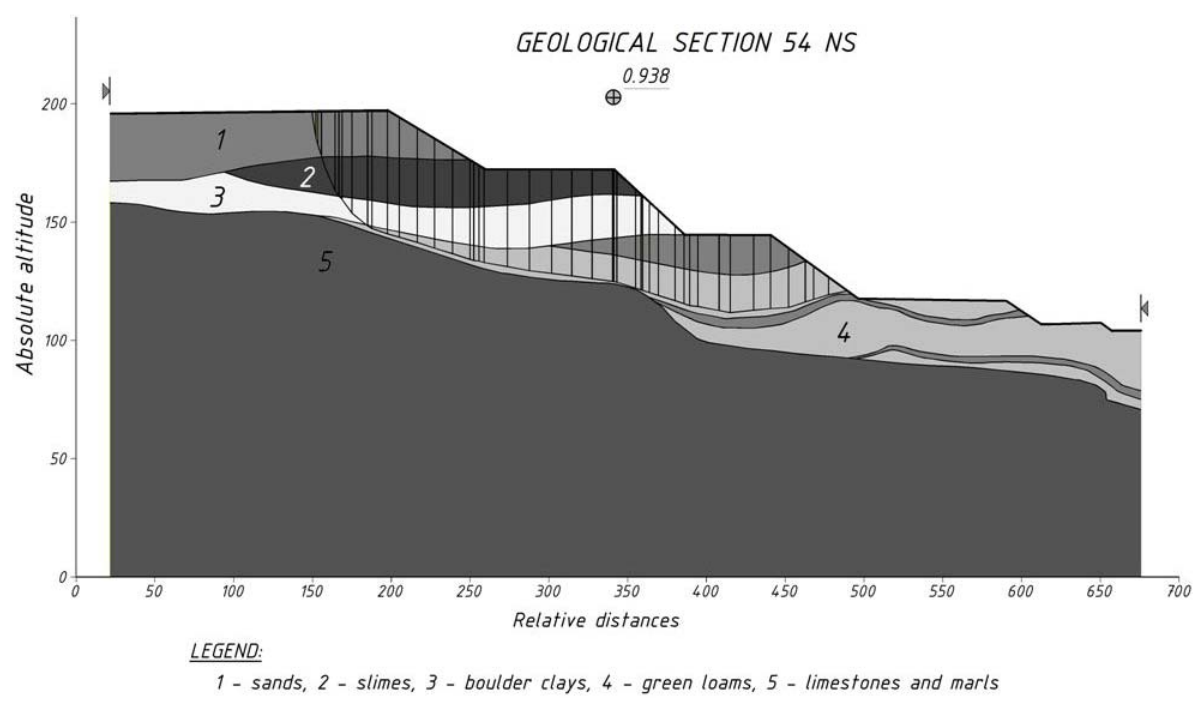

Figure 2: Geological cross-section through the landslide under investigation [25]

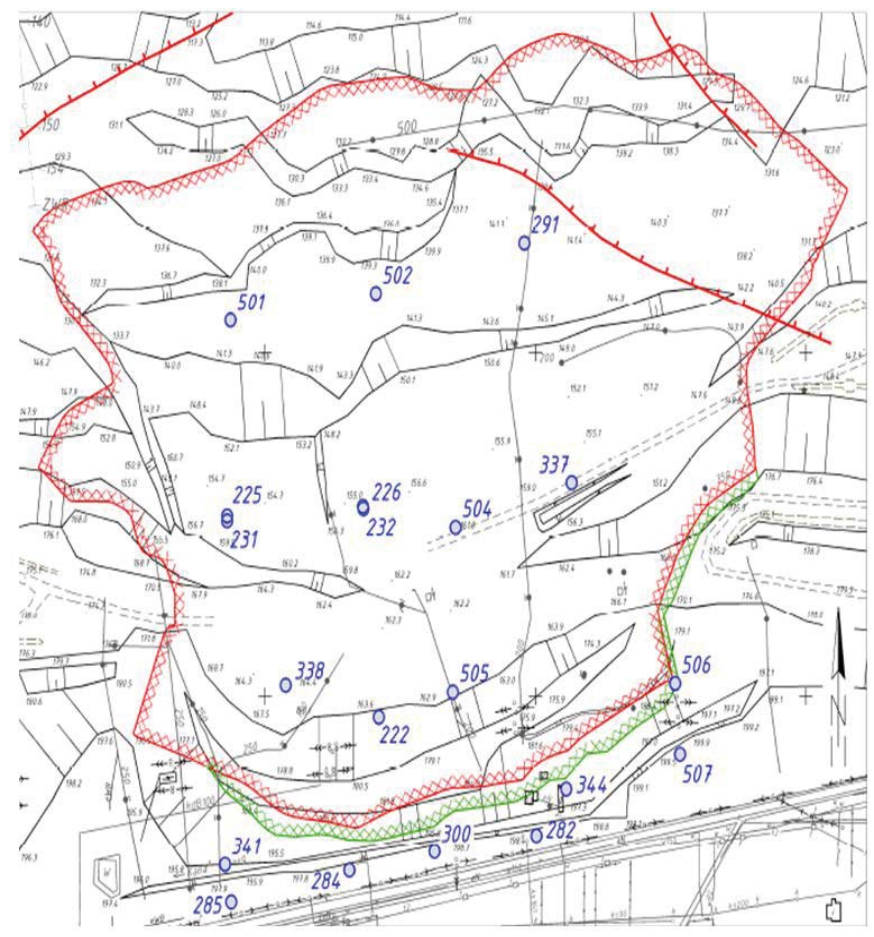

Figure 3: Localization of the points stabilized on the landslide area

The tests of the ground based interferometric radar IBIS $L$ were carried out to verify the possibility of its use in the monitoring of the landslide hazard in this particular mine.

The basic challenge was a large distance of the measurement (nearly $3 \mathrm{~km}$ ), as well as large landslide area (24 ha) and its large size $(580 * 594 \mathrm{~m})$.

\section{Ground based radar interferometry}

Ground based radar interferometry (GB-InSAR) is a remote technology, not requiring the entrance to the mon- itored landslide. In this technology, radar is used for the measurement. It is installed opposite to the measured object (in this case on the reverse slope, in the distance of $2.9 \mathrm{~km}$ ). The radar sends the beam of electromagnetic wave in the direction of the monitored surface; the wave reflects from the studied object and returns to the emitter, where this phase is recorded. The result of a single measurement containing information on the phases of the signal reflected from the area covered by the range of aerials, is recorded in the form of an image called radarogram (Fig. 5). Obtaining one radarogram takes up to 15 minutes.

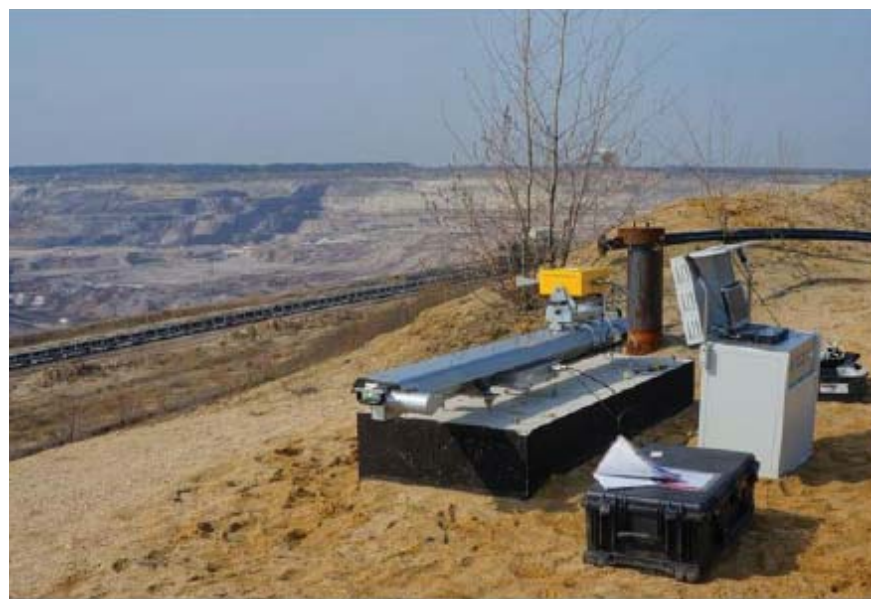

Figure 4: Radar IBIS L during measurement in open pit mine (photo A. Szafarczyk)

The radarogram consists 0.75 metre pixels at the direction of the wave emission and $4.5 \mathrm{mrad}$ at the direction perpendicular to the direction of the wave emission.

The displacement of the monitored surface is marked based on two radarograms made in any time interval, declared by the observer. Two overlapping radarograms give a 2D image called interferogram (Fig. 6). 


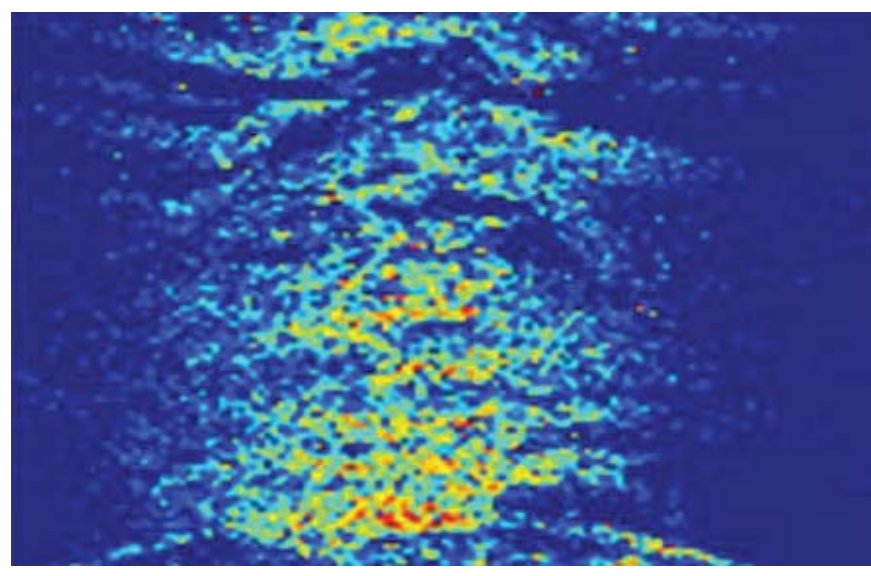

Figure 5: An example of a radarogram obtained during the carried out measurements

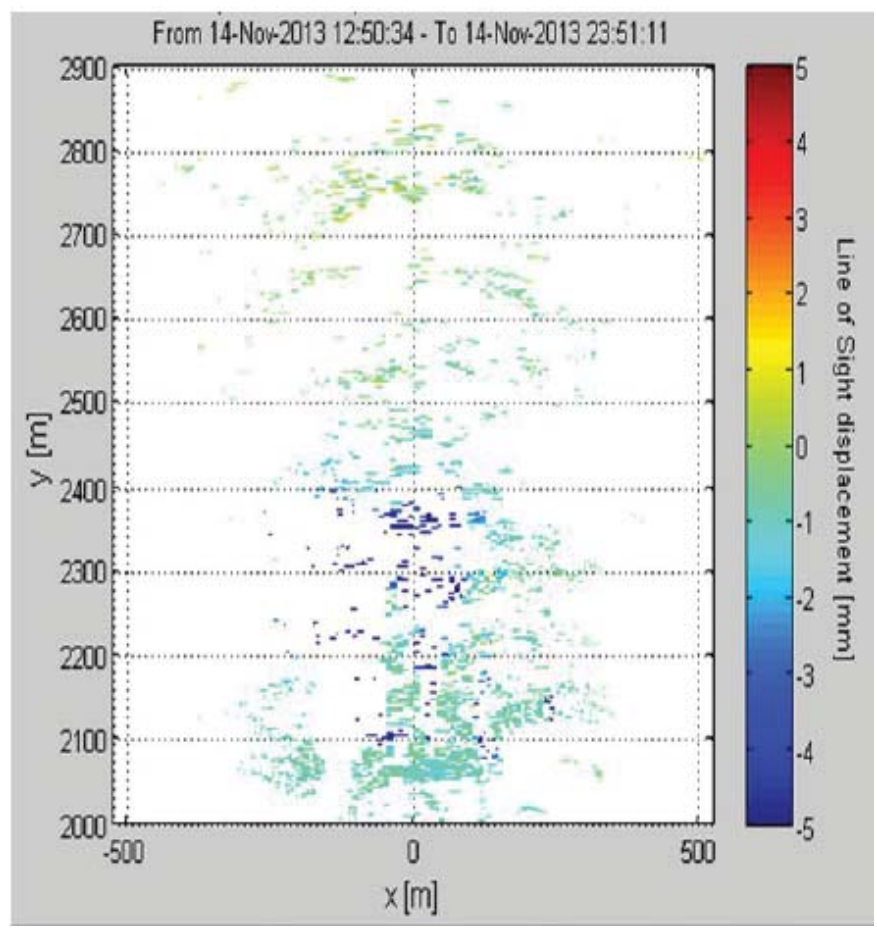

Figure 6: An example of iterferogram obtained during the carried out measurements

To enable the creation of an interferogram, radar imaging must be made from the same radar site. For this reason, the radar is installed on an aluminum rail placed on a concrete base.

Places, where the change of the phase of the returning signal, thus dislocation occurred are visible on the interferogram in the form of colourful pixels.

Based on the knowledge about phase dislocation of two radar images made in a certain time interval and with the knowledge of the wave length emitted by the radar applied in the measurement, the value of dislocation " $d$ " on the direction of the emitted wave is emitted, is determined, according to the formula: $d=-\frac{\lambda}{4 \pi}\left(\varphi_{2}-\varphi_{1}\right)$

where:

$\varphi_{1}$ - phase of the signal returning after reflection from the object in the first measurement,

$\varphi_{2}$ - the phase of the signal returning after reflection from the object in the second measurement,

$\alpha$ - wavelength.

During the measurement using a ground based interferometric radar, 38 radarograms were obtained. Making one full measurement allowing the generation of radarogram took about 12 minutes, then there was a 30 minutes' break. The measurement data were obtained for the same configuration of the radar sensor within the angular and distance resolution, as well as the declared maximal distance while making measurements, which provided homogeneity of the measurement data and the possibility of the generation of interferograms.

\section{ELIMINATION OF THE CYCLIC FACTOR FROM THE RESULTS OF GBINSAR MEASUREMENTS}

Processing the results of the measurements with the application of the ground based interferometric radar were made in the dedicated software IBIS DV. The range of the carried out radarograms was big enough to cover the area several times bigger than the studied landslide area. During the analyses the range of the analysed data diminished to the image covering 40 degrees in the horizontal direction (20 degrees to the left and right from the radar axis) and 2000 to 2900.5 metres in the direction of the distance.

\section{Introduction of the atmospheric correction to the measurement results}

Making interferograms without prior atmospheric correction leads to erroneous results and generates the possibility of drawing erroneous conclusions referring to the state of the dislocations of the studied object. Because of this, the results measurements were corrected based on so-called Ground Control Points (GCP), i.e. specially fixed signals called corner reflectors (Fig. 7), which indicates high reflexibility for radar waves, expressed in the value of signal to noise ratio (SNR).

It is recommended to select at least one GCP point to correct the influence of humidity and temperature on the measures values of dislocations for individual pixels of the image. GCPs must be presented on a radarogram in the form of pixels of high quality (wave reflexion) and occur in a stable area. While carrying the process of these studies, three GCPs were selected. They were localized above main scarp of the landslide being a subject of studies and in the distance of $2,8 \mathrm{~km}$ from the stand of the radar. 


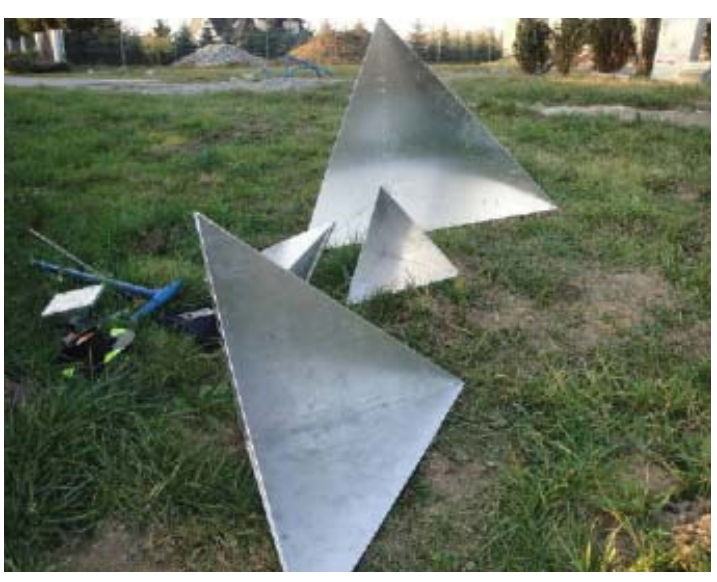

Figure 7: Corner reflectors (photo A. Szafarczyk)

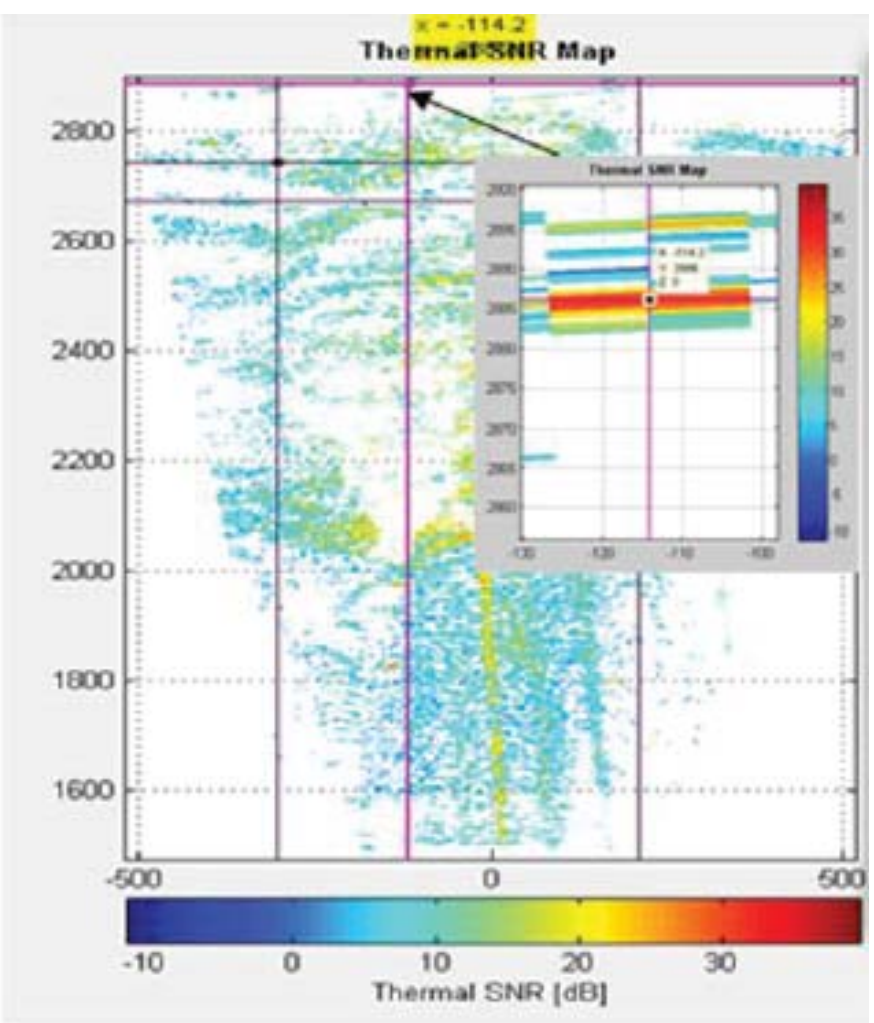

Generating interferograms using selected GCPs allowed the verification of the impact of the atmospheric conditions on the measurement results of the displacements of the studied landslide.

Taking into account the fact that the selected points GCP in fact are not subdued to any dislocation, the linear value of fictious dislocation, resulting only from the changeable atmospheric conditions can be determined. In the described case its extreme value is $12 \mathrm{~mm}$, which confirms large significance of the calibration of measurement results, especially in cases when we want to obtain millimetre accuracy. Assuming correction coefficient agcp calculated as:

$\alpha_{g c p}=\frac{d_{g c p}}{R_{g c p}}$,

where:

rdgcp - displacement of GCP,

Rgcp - distance between GCP and the radar,

one can check if the hypothesis on the influence of atmospheric conditions on the measurement results is correct and changes in atmospheric conditions have a linear distribution in space, as well as if GCPs are stable. If these premises are fulfilled, coefficient agcp should have the same value in all the selected GCPs.

In the examined case the extreme value of coefficient agcp was $0.8^{*} 10-3 \mathrm{~mm}$, which indicates very high quality of the introduced atmospheric correction and makes the proof of mutual dislocation of GCPs.

\section{INTERPRETATION OF INTERFEROGRAMS}

In the interferogram covering the time of 24 hours (Fig. 9) the points located in the regions characterized by the occurrence of dislocations of different values (region A, region $\mathrm{B}$, region $\mathrm{C}$ ) were selected.

Figure 8: Ground control point selection

Table 1: Ground control points characteristics

\begin{tabular}{|c|c|c|c|c|c|c|}
\hline GCP & $\mathrm{X}[\mathrm{m}]$ & $\mathrm{Y}[\mathrm{m}]$ & $\begin{array}{c}\text { Thermal } \\
\text { SNR [dB] }\end{array}$ & $\begin{array}{c}\text { Estimated } \\
\text { SNR [dB] }\end{array}$ & Coherence & $\begin{array}{c}\text { Phase } \\
\text { Stability }\end{array}$ \\
\hline GCP1 & $-114,2$ & 2886,1 & 29 & 18,5 & 0,62 & 2,82 \\
\hline GCP 2 & 212,0 & 2673,4 & 46,9 & 22,6 & 0,62 & 3,52 \\
\hline GCP3 & $-302,7$ & 2743,1 & 33,5 & 31,3 & 0,67 & 5,91 \\
\hline
\end{tabular}


REGION A

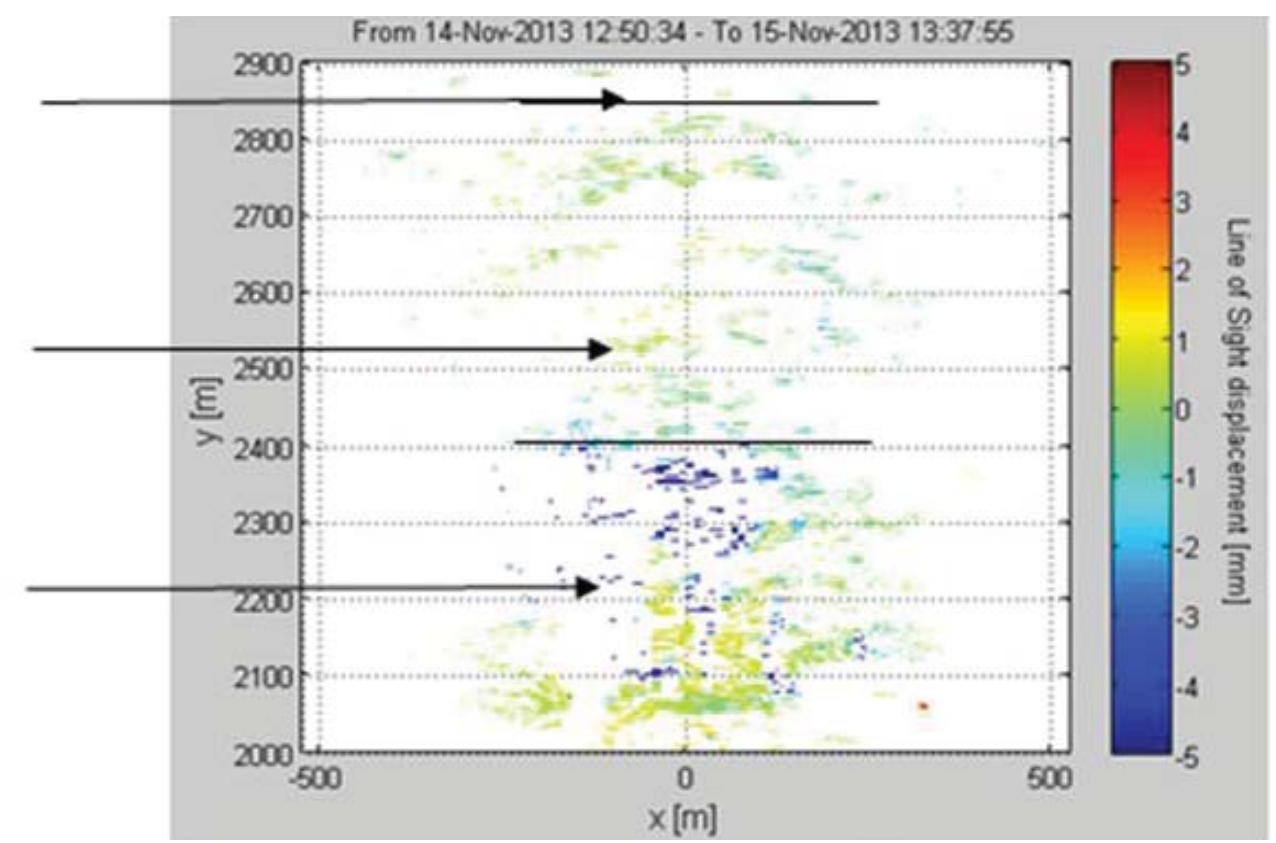

Figure 9: Displacement map for the 24 hours period

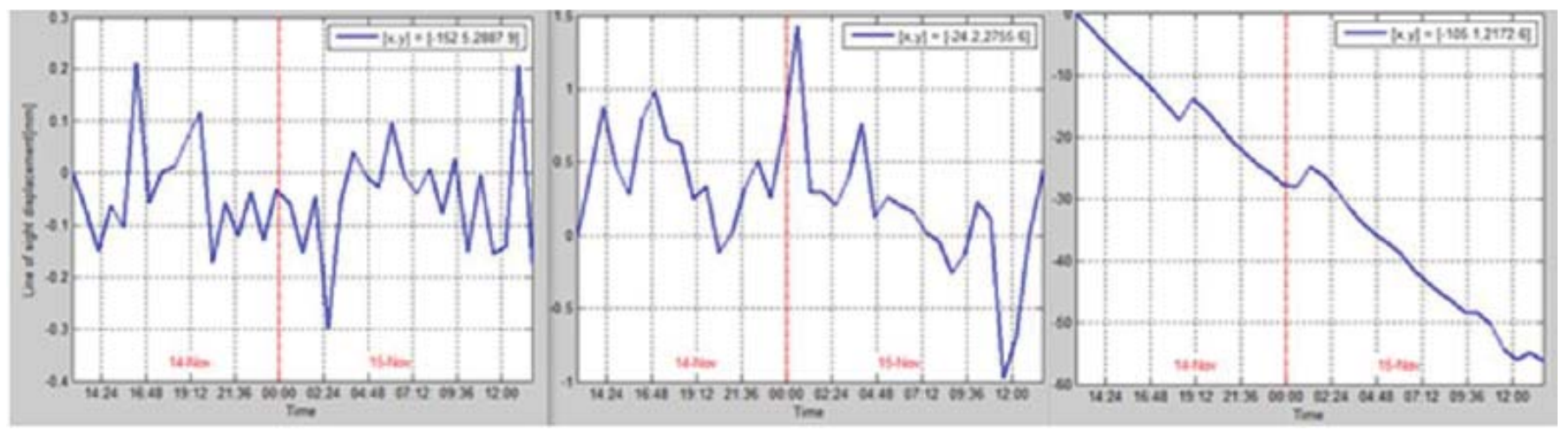

Figure 10: Selected pixel displacements (a) region A; (b) region B; (c) region $C$

In the area located over the upper scarp of the landslide (region marked as A) dislocation values were close to 0mm/24hours (Fig. 10A). This was a stable area and it did not pose hazard for the existing infrastructure.

Just below the main scarp, as well as in the whole inventoried area of the landslide (the region marked as B) no significant values of dislocations were observed. They oscillated around the value of $0 \mathrm{~mm} / 24$ hours, maximal values equalled $1.5 \mathrm{~mm} / 24 \mathrm{hours}$. The characteristics of the dislocations of one representative point of time, was presented graphically (Fig. 10B).

In the region below the lower border of the landslide (region marked as C) dislocations reaching $60 \mathrm{~mm} / 24$ hours were observed (Fig. 10C). For several selected pixels from this area the graphs of dislocations in time were made (Fig.11).

Based on the kinematics of the movement of the selected pixels corresponding the field points of region $\mathrm{C}$, one can state that they move at the rate ranging from about 10 to about $60 \mathrm{~mm} / 24$ hours (Fig. 11). Such values can classify the studied landslide, according to Varnes' classification, as slow or moderately fast. Dislocations have the character of the uniform motion with several moments of halting the process, the same as all points. These moments of halting the landslide movement are best visible in graph 15D and corresponds the measurement series carried out at the following hours of the local time: 19:02, 1:15 and 10:11. It is worth attention that the region below the landslide (region $\mathrm{C}$ ) (where there are no stabilized geodetic points) moves at the rate higher than the landslide itself.

Taking into account that the observations of the landslide process in this region are carried out on-line with the application of GPS technologies, it would be recommendable to stabilize additional several geodetic points. These points should be stabilized in the region limited by coordinates $\mathrm{Y}$ in the system of radar in the range from $2100 \mathrm{~m}$ to $2400 \mathrm{~m}$ and $X$ in the radar system ranging from $-200 \mathrm{~m}$ to $200 \mathrm{~m}$, which approximately corresponds coordinates $X$ in the system applied in the mine for the range from $41780 \mathrm{~m}$ to $42080 \mathrm{~m}$ and coordinates $\mathrm{Y}$ in the system applied in the mine for the range from $52000 \mathrm{~m}$ to $52400 \mathrm{~m}$. 


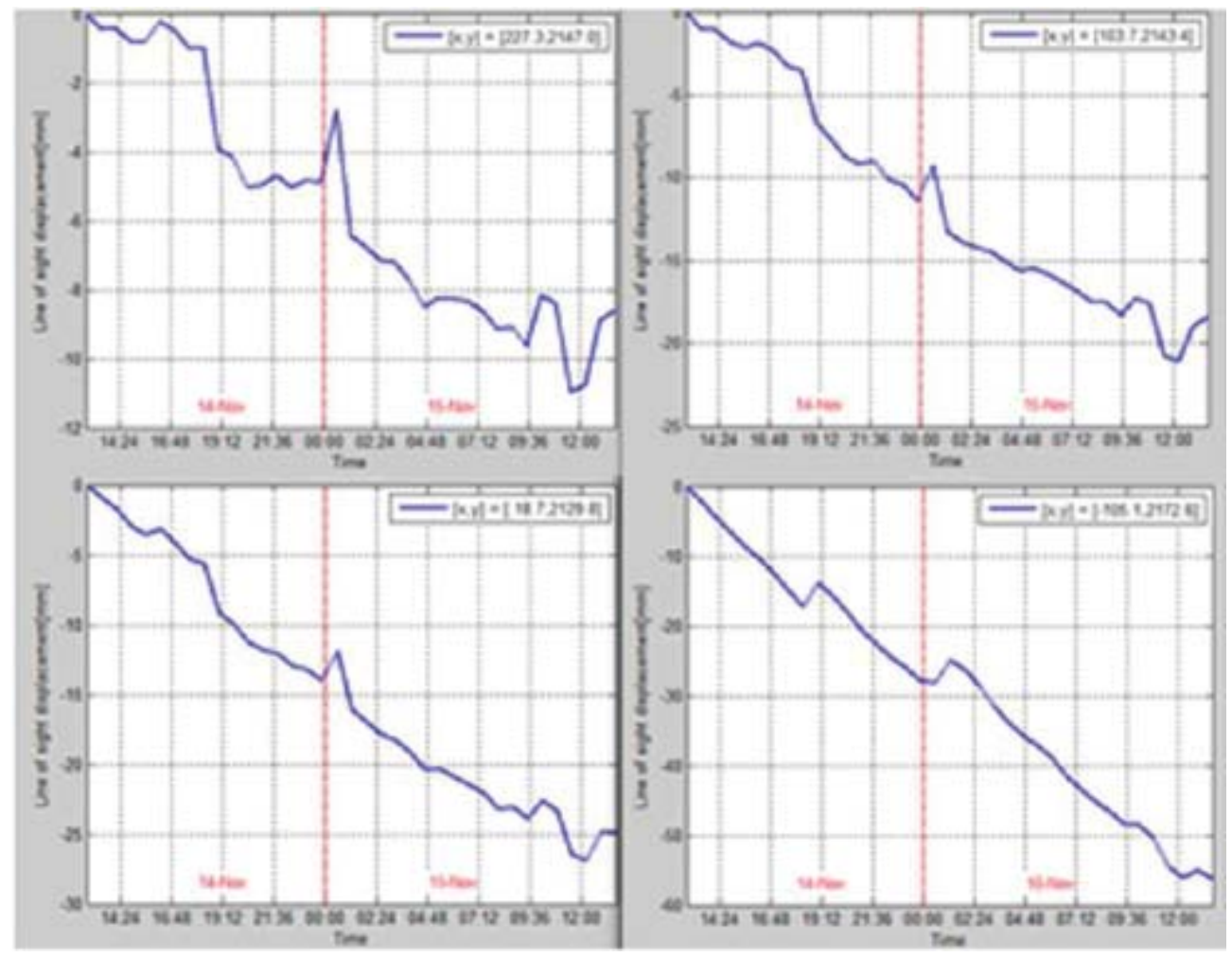

Figure 11: Selected pixels displacements located in region C in the function of time

\section{Comparison of the results obtained with the use of different measurement technologies}

The results of measurements with the application of GB-InSAR, were compared to the results obtained by classical technologies. The values of horizontal and vertical dislocations for all the points stabilized in the regions $A$ and $B$, then in the landslide area or in its direct vicinity (over the main scarp of the main landslide). Analysing the data referring to the coordinates $\mathrm{X}, \mathrm{Y}, \mathrm{H}$ of seventeen points obtained with the application of GPS RTK technologies and total stations, it was proved that six months before the studies, nine of these points were not dislocated, and eight were horizontally dislocated with the values from $0.15 \mathrm{~m}$ to $0.8 \mathrm{~m}$. Such values do not pose hazard in the case of landslide located in the excavation of the open cast mine.

Assuming linear character of the landslide process between the subsequent measurement series, it was established that the value of dislocations for the moveable points localized in region $B$, calculated to 24 hours maximally equal $4 \mathrm{~mm} / 24$ hours (Tab. 2).

In the region of the mentioned above points during the radar interferometry measurements, smaller values of dislocations were obtained. The reasons for the discrepancy are the following:

values of dislocations determined by the radar are not the values of horizontal dislocations, but the values of dislocations on the direction of the emission of the radar wave, the result of which is obtaining smaller values of dislocations than occurring in reality, values of dislocations calculated for 24 hours are very robust values, based on the assumption of the linearity of the deformation process and interpolation between the results of measurements carried out in the interval of the week.

For unquestionable verification of the values of determined dislocations in the considered conditions, one should carry out classical geodetic measurements with higher frequency (every day or even several times a day), as well as in their place, in an unstable area - put GCPs (corner reflectors) to unambiguously verify the value of the determined dislocations.

Table 2: Displacements of the stabilized points located in region $A$ and $B$

\begin{tabular}{|c|c|c|}
\hline Point & Dislocation & Dislocation \\
\hline & $\begin{array}{c}\text { (measurement } \\
\text { GPS RTK and } \\
\text { total stations) } \\
\text { [m/24 hours] }\end{array}$ & $\begin{array}{c}\text { (measurement } \\
\text { GB-InSAR) } \\
\text { [m/24 hours }]\end{array}$ \\
\hline 291 & 0,003 & \multirow{2}{*}{$0,000 \div 0,0015$} \\
\hline 337 & 0,002 & \multirow{2}{*}{0,0007} \\
\hline 342 & 0,001 & \\
\hline 343 & 0,002 & \\
\hline 501 & 0,004 & \\
\hline 502 & \multicolumn{2}{|c|}{} \\
\hline
\end{tabular}


In region $\mathrm{C}$, in which the greatest values of dislocations were observed, the verification of their values with the results of classical measurements was not possible because of the lack of the points of the grid in this region.

\section{CLOSING REMARKS AND CONCLUSIONS}

A modern instrument IBIS L, based on the technology of interferometry can be used in precise measurements of long-lasting dislocations and short-lasting dislocations (vibrations). Impossible so far such a big precision and high accuracy and frequency of the data recording, the possibility of measurements without the need for the access to the object and the easiness of the use of measurement make this instrument very useful in the measurement dislocations. Obtaining results giving the possibility of making conclusions about the state of the monitored object in a real time, allows the statement that it can be applied in the studies of the deformation of the objects and areas particularly dangerous, making hazard for health and life, as well as the areas where the access is impossible.

The applied instrument can successfully monitor the landslide of the surface of several hectares from the distance of 3 kilometres.

It is also worth mentioning that the image of dislocations obtained with the application of technology of ground based radar interferometry, gives the information on the region of landslide in the range of the determined limits, on which geodetic points are stabilized, but also about the area beyond its limits, which marked the range of the existing landslide.

\section{REFERENCES}

1. Varnes, DJ. (1978). Slope movement types and processes. In Special report 176: Landslides: Analysis and Control, Transportation Research Board, Washington, D.C.

2. Cruden D.M., Varnes D.J. (1996), Landslide types and processes. In Special Report 247: Landslides: Investigation and Mitigation, Transportation Research Board, Washington D.C.

3. Savarensky F.P.(1981), Landslides, landslides classification. Engineering geology reference book. "Nedra" Publishers, Moscow, p. 87-88.

4. Pavlov A. P.(1968), Landslide general classifications. Engineering geology reference book. "Nedra" Publishers, Moscow, p. 181.

5. Sharpe C.F.(1938), Landslides and related phenomena. New York: Columbia University Press, p. 1370.

6. Bydłosz J., Hanus P. (2013), The impact of landslide areas on municipal spatial planning. Real Estate Management and Valuation. vol. 21, no. 4, pp. 5-10. DOI: 10.2478/remav-2013-0031.
7. Puniach E., Bieda A., Ćwiąkała P., Kwartnik Pruc A., Parzych P. (2018), Use of unmanned aerial vehicles (UAVs) for updating farmland cadastral data in areas subject to landslides. ISPRS International Journal of Geo-Information. vol. 7 iss. 8 art. no. 331, pp. 1-19.

8. Pilecki Z. (2017), Basic principles for the identification of landslides using geophysical methods. E3S Web of Conferences, 24 (2017) 01001, DOI: https:// doi.org/10.1051/e3sconf/20172401001

9. Kroh P., Strus P., Gorczyca E., Wronska-Walach D., Dlugosz M. (2014) Identyfikacja osuwisk w gminie Łososina Dolna na podstawie danych lotniczego skanowania laserowego. Problemy Ekologii Krajobrazu. vol. 38, pp. 61-75.

10. Wojciechowski T., Perski Z. (2008) Zastosowanie satelitarnej interferometrii radarowej do określenia aktywności osuwisk obrzeżenia Kotliny Sądeckiej. Archiwum Fotogrametrii, Kartografii i Teledetekcji. Vol. 18b, pp. 697-706

11. Ilcewicz-Stefaniuk D., Lemberger M., Magiera J., Rybicki S., Słomka T., Stefaniuk M. (2004) Cataloguing natural geological hazards over Poland's territory. Polish Geological Institute Special Papers. vol. 15, pp. 53-60.

12. Rybicki, S., Czarnecki L., Organiściak B. (2000) Zagrożenia geotechniczne w KWB „Bełchatów”, ich uwarunkowania, możliwości prognozy oraz zapobiegania. Materiały Sympozjum „25 lat doświadczeń KWB Bełchatów”. Bełchatów 17-18 stycznia 2000. SITG KWB „Bełchatów”, 19-26.

13. Terzaghi K.: Mechanism of Landslides, Engineering Geology (Barkey) November 1950, reprintFrom Theory to practice In soil mechanics. N. York, J. 1950

14. Wysokiński L. (1980) Kryterium dynamiki zboczy. Biuletyn Instytutu Geologicznego Nr 324.

15. Czarnecki L., Jończyk W., Organiściak B., Wysokiński L. (2007), Zagrożenia geotechniczne w wyrobisku górniczym kopalni Bełchatów. ITB Warszawa.

16. Maciaszek J., Gawałkiewicz R., Szafarczyk A.(2015), Surveying methods of landslide studies (in Polish). Wydawnictwa AGH. p. 123.

17. Gili, J.A., Corominas, J., \& Rius, J. (2000). Using Global Positioning System techniques in landslide monitoring. Engineering Geology, 55(3), 167-192. doi:10.1016/s0013-7952(99)00127-1

18. Tarchi, D., Casagli, N., Fanti, R., Leva, D.D., Luzi, G., Pasuto, A., . . . Silvano, S. (2003). Landslide monitoring by using ground-based SAR interferometry: an example of application to the Tessina landslide in Italy. Engineering Geology, 68(1-2), 15-30. doi:10.1016/s0013-7952(02)00196-5 
19. Monserrat, O., Crosetto, M., \& Luzi, G. (2014). A review of ground-based SAR interferometry for deformation measurement. ISPRS Journal of Photogrammetry and Remote Sensing, 93, 40-48. doi:10.1016/j. isprsjprs.2014.04.001

20. Bozzano, F., Cipriani, I., Mazzanti, P., \& Prestininzi, A. (2011). Displacement patterns of a landslide affected by human activities: insights from groundbased InSAR monitoring. Natural Hazards, 59(3), 1377-1396. doi:10.1007/s11069-011-9840-6

21. Luzi, G., Pieraccini, M., Mecatti, D., Noferini, L., Macaluso, G., Galgaro, A., \& Atzeni, C. (2006). Advances in groundbased microwave interferometry for landslide survey: a case study. International Journal of Remote Sensing, 27(12), 2331-2350. doi:10.1080/01431160600554975

22. Noferini, L., Pieraccini, M., Mecatti, D., Macaluso, G., Atzeni, C., Mantovani, M., . . . Tagliavini, F. (2007). Using GB-SAR technique to monitor slow moving landslide. Engineering Geology, 95(3-4), 8898. doi:10.1016/j.enggeo.2007.09.002
23. Lenda, G., Ligas, M., Lewińska, P., \& Szafarczyk, A. (2016). The use of surface interpolation methods for landslides monitoring. KSCE Journal of Civil Engineering, 20(1), 188-196. doi:10.1007/s12205-0150038-4

24. Szafarczyk, A., \& Gawałkiewicz, R. (2016). Case study of the tensor analysis of ground deformations evaluated from geodetic measurements in landslide area. Acta Geodynamica et Geomaterialia, 201-211. doi:10.13168/agg.2016.0003

25. Szafarczyk, A. Rybicki S. et al (2013), Study of the kinematics of surface mass movements using ground-based radar interferometry, Wydawnictwa AGH, ISBN: 978-83-7464-648-2, p. 126. 